\title{
Cloning and Characterization of a Member of the Xanthomonas avr/pth Gene Family That Evades All Commercially Utilized Cotton $\boldsymbol{R}$ Genes in the United States
}

\author{
P. K. Chakrabarty, Y. P. Duan, and D. W. Gabriel
}

Plant Pathology Department, University of Florida, Gainesville 32611.

Accepted for publication 1 August 1997.

ABSTRACT

\begin{abstract}
Chakrabarty, P. K., Duan, Y. P., and Gabriel, D. W. 1997. Cloning and characterization of a member of the Xanthomonas avr/pth gene family that evades all commercially utilized cotton $R$ genes in the United States. Phytopathology 87:1160-1167.

The highly virulent African strains of Xanthomonas campestris pv. malvacearum are quarantined pathogens in the United States and can evade or overcome all commercially utilized resistance $(R)$ genes in cotton grown in the United States including the entire set of host differential lines used to distinguish 19 races of the pathogen. Nevertheless, the African strains carry multiple DNA fragments that strongly hybridize with members of the Xanthomonas avirulence (avr)/pathogenicity (pth) gene family. Since all previously tested members of the gene family confer avirulence against one or more $R$ genes in cotton, strains carrying multiple members might not be expected to evade so many different $R$ genes. The hybridizing DNA fragments were cloned from African strain
\end{abstract}

$\mathrm{XcmN}$ and found to confer water-soaking ability to a nearly asymptomatic mutant strain of the pathogen. Restriction mapping, Southern hybridization, and DNA sequencing of the cloned fragments from $\mathrm{XcmN}$ were used to identify two water-soaking genes, $p t h N$ and $p t h N 2$, as new members of the Xanthomonas avr/pth gene family. The complete DNA sequence of $p t h N$ was obtained, and it is $>94 \%$ identical with all other sequenced members of the gene family. Gene fusions of pthN with avrb6 (another family member) and other experiments revealed that the ability of African strain $\mathrm{XcmN}$ to water-soak cotton and avoid recognition by commercially used cotton $R$ genes is determined by the specific repeats of multiple functional members of the Xanthomonas avr/pth gene family.

Additional keywords: cotton blight, gene-for-gene, Gossypium hirsutum, race specificity.
Strains of Xanthomonas campestris pv. malvacearum that cause bacterial blight of cotton (Gossypium spp.) exhibit gene-for-gene (also known as cultivar or race) specificity $(8,10,16)$. There are at least 19 well-described races of the pathogen (2). The genetics of resistance of Gossypium to this pathogen is also well described, with at least 16 different resistance $(R)$ genes identified (11). Different $X$. campestris pv. malvacearum races contain different combinations of avirulence (avr) genes that define the race and determine cultivar specificity. Host cultivars containing $R$ genes respond to avirulent races with a hypersensitive response (HR). Ten $a v r$ genes were cloned and characterized from a single North American strain of $X$. campestris pv. malvacearum, $\mathrm{XcmH}$, and most of these $a v r$ genes genetically "recognize" multiple $R$ gene loci in an $a v r$ gene-for- $R$ genes (plural $R$ genes) manner $(7,10)$. These 10 genes belong to a large family of Xanthomonas avr/pth genes that composes most of the Xanthomonas avr genes cloned to date (15). All of these avrlpth genes that have been sequenced so far are nearly identical (some of them $>97 \%$ identical) in DNA sequence; not surprisingly, several individual cotton $R$ gene loci genetically "recognize" multiple members of the avrlpth gene family in an $R$ gene-for- $a v r$ genes (plural $a v r$ genes) manner (10). These $a v r$ genes are, therefore, less gene-for-gene specific than most others described to date.

Although most members of the Xanthomonas avr/pth gene family were originally cloned as $a v r$ genes, some members of this

Corresponding author: D. W. Gabriel; E-mail address: gabriel@biotech.ufl.edu

Publication no. P-1997-0915-01R

(c) 1997 The American Phytopathological Society gene family also confer ability to elicit host-specific, pathogenic symptoms. For example, at least seven $X$. campestris pv. malvacearum avr/pth genes can contribute to water-soaking symptoms on susceptible cotton plants $(31,33)$. In addition, a pathogenicity (pth) gene, $p t h A$, is required by $X$. citri to cause hyperplastic canker symptoms on citrus and was originally cloned as a pathogenicity gene (28). However, all previously cloned members tested, including $p t h A$, confer avirulence to $X$. campestris pv. malvacearum against multiple $R$ genes $(10,29)$.

Some highly virulent strains of $X$. campestris pv. malvacearum isolated in West Africa are virulent on all commercial cotton lines used in the United States, including the long-established, "immune" cotton line 101-102B, and all differential host lines (2,13). A new cultivar, S295, developed and used in Africa, has a single gene (B12) that is effective for resistance against all African strains reported to date (30). However, single genes for resistance are frequently overcome by mutation at cognate $a v r$ loci (18), and the $X$. campestris pv. malvacearum avr/pth genes undergo intergenic and intragenic recombination, generating race change variants at high frequency $(10,32)$. Commercial use of a single effective $R$ gene, such as $B 12$, against a pathogen exhibiting a high level of race change variation may be unwise from a statistical point of view $(21,25)$, unless there is some other reason to believe that the $R$ gene will be longer lasting than most. Therefore, we wished to determine the molecular basis of virulence of the African strains.

The molecular basis of the high level of virulence of the African strains could be due to any one of several possibilities. One possibility is that the African strains lack functional or active avr/pth genes, even though Southern hybridization with members of the gene family revealed the presence of at least four potential Xan- 
thomonas avr/pth homologues in each of these strains tested (10). Another possibility is suppression of phenotypic avirulence by other genes in the African strains; avr gene suppression has been observed at independent loci with both wheat leaf rust and flax rust pathogens $(22,26)$. A third possibility is that the $a v r /$ pth homologues indicated by hybridization are functional and active pathogenicity genes, but lack avirulence activity against any of the commercially utilized $R$ genes. The purpose of this investigation was to distinguish between these three different possibilities.

We report here evidence that the latter possibility is the case and that (i) the African strain $\mathrm{XcmN}$ carries active avr/pth genes that confer pathogenicity (water-soaking), but not avirulence, on commercial cotton grown in the United States; (ii) the complete DNA sequence of $p t h N$ and partial sequence of $p t h N 2$ reveal that these pathogenicity genes are members of the Xanthomonas avr/pth gene family; and (iii) the 102-bp tandem repeat region of $p t h N$ determines pathogenicity without avirulence on commercial U.S. cotton, but is recognized by the $B 12$ gene in S295 as an $a v r$ gene.

\section{MATERIALS AND METHODS}

Bacterial strains, plasmids, and culture media. Strains of Escherichia coli, X. campestris pv. malvacearum, and plasmids used in this study are listed in Table 1 . Strains of E. coli were grown in Luria-Bertani (LB) medium (27) at $37^{\circ} \mathrm{C}$. X. campestris pv. malvacearum strains were cultured on PYGM (peptone-yeast extractglycerol-morpholinepropanesulfonic acid) medium at $30^{\circ} \mathrm{C}(9)$. For culture on solid media, agar was added at $15 \mathrm{~g} / \mathrm{liter}$. Antibiotics were used at the following final concentrations: ampicillin, $30 \mathrm{mg} / \mathrm{liter}$ for low copy vectors and $100 \mathrm{mg} /$ liter for high copy vectors; kanamycin, $25 \mathrm{mg} /$ liter; gentamicin, $5 \mathrm{mg} / \mathrm{liter}$; spectinomycin, $50 \mathrm{mg} / \mathrm{liter}$; tetracycline, $15 \mathrm{mg} /$ liter; rifampicin, $75 \mathrm{mg} / \mathrm{liter}$; and chloramphenicol, $35 \mathrm{mg} /$ liter.

Recombinant DNA techniques. Plasmids were isolated from E. coli by alkaline lysis, and standard recombinant DNA procedures were as described (27). Restriction enzyme digestion, alkaline phosphatase treatment, DNA ligation, Southern blots on nylon membranes, and random priming reactions were performed as recommended by the manufacturers.

TABLE 1. Bacterial strains and plasmids used in this study

\begin{tabular}{|c|c|c|}
\hline Strain or plasmid & Relevant characteristics ${ }^{\mathrm{a}}$ & Reference \\
\hline \multicolumn{3}{|l|}{ E. coli } \\
\hline DH5 & $\mathrm{F}-$, endA1, hsdR17 $\left(\mathrm{r}_{\mathrm{k}}{ }^{-} \mathrm{m}_{\mathrm{k}}{ }^{+}\right)$, supE44, thi-1, recA1, gyrA, relA1, 80dlacZ M15, (lacZYA-argF)U169 & Gibco BRL ${ }^{b}$ \\
\hline DH5 $\alpha$ MCR & DH5 mcrA mcrBC mrr & Gibco BRL ${ }^{b}$ \\
\hline \multicolumn{3}{|c|}{ Xanthomonas campestris pv. malvacearum } \\
\hline $\mathrm{XcmN}$ & $\begin{array}{l}\text { Natural isolates from cotton from Upper Volta, Africa; virulent on all cotton differential lines including Stoneville 2B-S9, } \\
\text { Stoneville 20, Mebane B-1, 1-10B, 20-3, 101-102B, Gregg, Empire B4, and DPxP4, but avirulent on S295 }\end{array}$ & $\begin{array}{l}7,16,23 \\
\text { and this study }\end{array}$ \\
\hline Xcm1003 & Spontaneous $\mathrm{Spc}^{\mathrm{r}} \mathrm{Rif}^{\mathrm{r}}$ derivative of $\mathrm{XcmN}$ & 7 \\
\hline $\mathrm{XcmH}$ & Natural race 4 isolate from cotton; carries $10 \mathrm{avr} / \mathrm{pth}$ genes & 16 \\
\hline $\mathrm{XcmH} 1005$ & Spontaneous Rif ${ }^{\mathrm{r}}$ derivative of $\mathrm{XcmH}$ & 31 \\
\hline HM2.2S & $a v r B 4^{-}, a v r B 5^{-}, a v r b 6^{-}, a v r B n^{-}, a v r B I n^{-}, a v r B 101^{-}, a v r 102^{-}$, and marker-evicted mutant derivative of XcmH1005 & 33 \\
\hline \multicolumn{3}{|c|}{ X. campestris pv. alfalfae } \\
\hline $\mathrm{KX}-1$ & Spontaneous $\mathrm{Spc}^{\mathrm{r}}$ derivative of $\mathrm{KS}$, isolated from alfalfa & 24 \\
\hline \multicolumn{3}{|l|}{ Plasmids } \\
\hline pBluescript II KS & ColE1, Ap ${ }^{\mathrm{r}}$, lac $^{+}$, high copy vector & Stratagene ${ }^{\mathrm{c}}$ \\
\hline pRK2013 & ColE1, $\mathrm{Km}^{\mathrm{r}}, \mathrm{Tra}^{+}$, conjugation helper plasmid & 12 \\
\hline pUFR042 & $\mathrm{IncW}, \mathrm{Nm}^{\mathrm{r}}, \mathrm{Gm}^{\mathrm{r}}, \mathrm{Mob}^{+}, \operatorname{mob}(\mathrm{P}), \operatorname{lac} Z^{+}, \mathrm{Par}^{+}, \cos$, shuttle vector & 7 \\
\hline pUFR043 & $\mathrm{IncW}, \mathrm{Mob}^{+}, \operatorname{lac}^{+}, \mathrm{Gm}^{\mathrm{r}}, \mathrm{Nm}^{\mathrm{r}}, \cos$, shuttle vector & 7 \\
\hline pUFR047 & IncW, $\mathrm{Gm}^{\mathrm{r}}, \mathrm{Ap}^{\mathrm{r}}, \mathrm{Mob}^{+}, \operatorname{lacZ}^{+}, \mathrm{Par}^{+}$, shuttle vector & 10 \\
\hline pUFR053 & $\mathrm{IncW}, \mathrm{Gm}^{\mathrm{r}}, \mathrm{Cm}^{\mathrm{r}}, \mathrm{Mob}^{+}, \mathrm{lacZ}^{+}, \mathrm{Par}^{+}$, shuttle vector & Yuan and Gabriel ${ }^{\mathrm{d}}$ \\
\hline pUFR054 & IncP, $\mathrm{Tc}^{\mathrm{r}}, \mathrm{Mob}^{+}$, containing methylases $\mathrm{XmaI}$ and $\mathrm{XmaIII}$ & 8 \\
\hline pUFR135 & $2.9-+0.5-\mathrm{kb}$ BamHI fragments from XcmH containing intact avrb6 in pUFR042; lacZ::avrb6 & 10 \\
\hline pQY104.3 & 3.4-kb internal BamHI fragment of pthA cloned in pUC19 & Yuan and Gabriel ${ }^{\mathrm{d}}$ \\
\hline pPKC5 & Cosmid clone containing $36.7-\mathrm{kb}$ insert from $\mathrm{XcmN}$ genome carrying $p t h N$ and $p t h N 2$ in pUFR043 & This study \\
\hline pPKC5.1 & 14-kb EcoRI fragment from pPKC5 in pUFR047 & This study \\
\hline pPKC5.2 & 2.6-kb EcoRI fragment from pPKC5 in pUFR047 & This study \\
\hline pPKC5.3 & 8.7-kb EcoRI fragment from pPKC5 carrying $p t h N$ and $p t h N 2$ in pUFR047 & This study \\
\hline pPKC5.5 & 8.7-kb EcoRI fragment from pPKC5, opposite in orientation from pPKC5.3 & This study \\
\hline pPKC5.30 & 0.7-kb EcoRI fragment from pPKC5 in pUFR047 & This study \\
\hline pPKC6.1 & Partial subclone of pPKC5 containing 10.7-kb fragment only & This study \\
\hline pPKC6.10 & Partial subclone of pPKC5 containing 10.7- and 8.7-kb fragments & This study \\
\hline pPKC6.19 & Partial subclone of pPKC5 containing 14-, 10.7-, 8.7-, and 2.6-kb fragments & This study \\
\hline pPKC6.58 & Partial subclone of pPKC5 containing 10.7-, 8.7-, and 2.6-kb fragments & This study \\
\hline pPKC8.37 & pPKC5.3 religated following restriction digestion with Sst II; contains $3.0-\mathrm{kb} p t h N$ fragment, truncated $1.0-\mathrm{kb}$ at the $5^{\prime}$ end & This study \\
\hline pPKC9.1 & 5.4-kb SstII/HindIII fragment of pPKC5.3 containing pthN2 in pBluescript KS & This study \\
\hline pPKC10.1 & 5.4-kb SstI/HindIII fragment containing pthN2 from pPKC9.1 in pUFR053 & This study \\
\hline pPKC13.12 & 3.5-kb $P v u \mathrm{II}$ fragment from pPKC5.3 containing $p t h N$ truncated $500 \mathrm{bp}$ at the $3^{\prime}$ end, in $S m a \mathrm{I}$ site of pBluescript KS & This study \\
\hline pPKC14.2 & 3.5-kb SstI/HindIII fragment containing pthN from pPKC13.12 in pUFR047 & This study \\
\hline pPKC15.2 & 3.0-kb Sst II/EcoRI fragment from pPKC8.37, containing $p t h N$ truncated $1.0-\mathrm{kb}$ at the $5^{\prime}$ end in pBluescript $\mathrm{KS}$ & This study \\
\hline pPKC18.5 & 4.0-kb SstI/HindIII fragment containing intact $p t h N$ in pBluescript $\mathrm{KS}$ & This study \\
\hline pPKC19.4 & 4.0-kb SstI/HindIII fragment containing intact $p t h N$ in pUFR047 & This study \\
\hline pPKC22.6 & Chimeric gene carrying 1.6-kb StuI/AatII fragment of avrb6 from pUFR135, replacing 102-bp pthN repeats in pPKC18.5 & This study \\
\hline pPKC24.1 & 4.0-kb SstI/HindIII fragment containing chimeric gene from pPKC22.6 in pUFR047 & This study \\
\hline
\end{tabular}

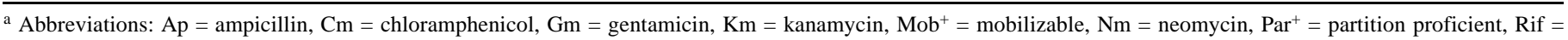
rifampicin, $\mathrm{Spc}=$ spectinomycin, $\mathrm{Tc}=$ tetracycline, and $\mathrm{Tra}^{+}=$self-transmissible.

b Gibco BRL, Gaithersburg, MD.

c Stratagene Inc., La Jolla, CA.

${ }^{\mathrm{d}} \mathrm{Q}$. Yuan and D. W. Gabriel, unpublished data. 
Construction of the DNA library. Total DNA of XcmN was prepared as described (17) and purified by cesium chloride-ethidium bromide density centrifugation. The genomic DNA was partially digested by Sau3A and size-fractionated using sucrose density gradient centrifugation. DNA fragments in the size range of 35 to $40 \mathrm{~kb}$ were used for the construction of the library in pUFR043, as described (6). The recombinant linear fragments were packaged into phage heads with Gigapack Gold Packaging Mix (Stratagene Inc., La Jolla, CA) and transduced into E. coli strain DH5 $\alpha$ MCR, following manufacturer's instructions. Individual clones in the library were selected on LB agar medium containing kanamycin and stored in LB broth containing $14 \%$ glycerol in microtiter dishes at $-70^{\circ} \mathrm{C}$.

Colony hybridization and bacterial conjugation. Each of the 846 clones in the DNA library was transferred to nylon membranes using a sterile, 46-pronged colony replicator. Colonies were lysed on the membrane and the DNA bound to the membrane exactly as described (27). Colony hybridization was done using ${ }^{32} \mathrm{P}$ labeled pQY104.3. Phenotypic activities of E. coli library clones were tested by mobilizing the clones into Xcm1003 or mutant strain HM2.2S (33) of X. campestris pv. malvacearum. Transfer of DNA was accomplished by triparental mating using pRK2013 as a transfer helper and pUFR054 to methylate the DNA as described (8). Transconjugants in X. campestris pv. malvacearum were selected on PYGM agar containing appropriate antibiotics.

Plant inoculations. The cotton (G. hirsutum) line used for watersoaking activity assays was Acala 44 (Ac44); its congenic resistant lines Acb6 and AcBIn3 were used for avirulence activity assays (assessed visually as a macroscopic HR). A set of cotton differential lines including AcB1, AcB2, AcB4, Acb6, Acb7, AcBIn, AcBIn3; the standard set of cotton differential lines $(8,11,31)$ composed of Stoneville 2B-S9, Stoneville 20, Mebane B-1, 1-10B, 203, 101-102B, Gregg, Empire B4, and DPxP4; and S295 were also used for avirulence activity assays. For heterologous system assays, $X$. campestris pv. malvacearum genes were transferred into $X$. campestris pv. alfalfae strain $\mathrm{KX}-1$ and inoculated onto common bean

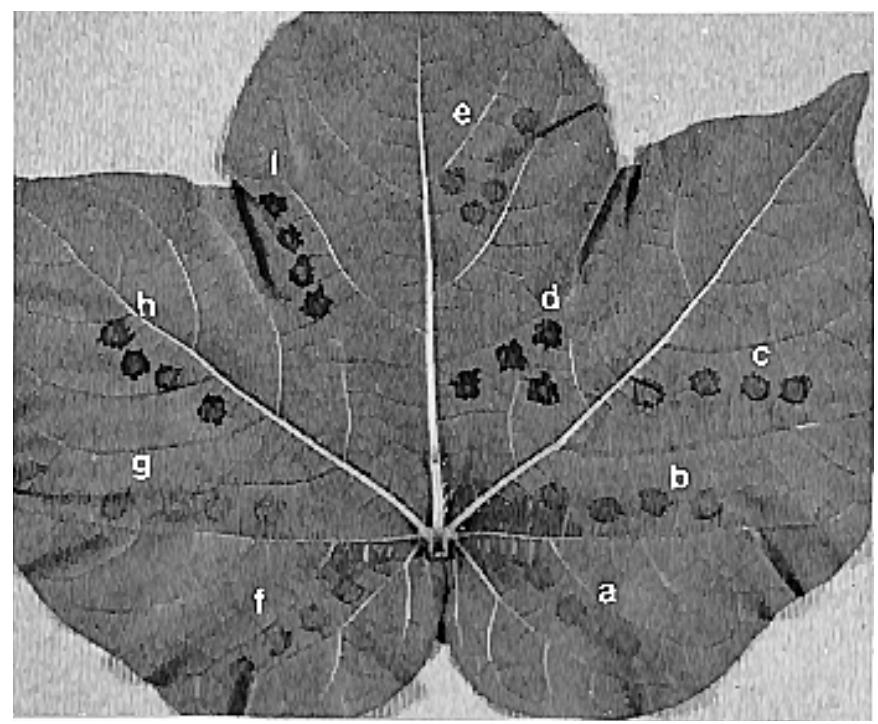

Fig. 1. Water-soaking activity assays of cosmid clones from the $\mathrm{XcmN}$ library selected on the basis of hybridization to an internal BamHI fragment of $p t h A$ (avirulence $[a v r] /$ pathogenicity $[p t h]$ family member). The clones were conjugated into Xanthomonas campestris pv. malvacearum strain HM2.2S and inoculated on Acala 44 cotton at high levels $\left(10^{8} \mathrm{CFU} / \mathrm{ml}\right.$; HM2.2S is asymptomatic at $10^{6} \mathrm{CFU} / \mathrm{ml}$ ): a, HM2.2S/pUFR043 (vector); b, HM2.2S/ pPKC2; c, HM2.2S/pPKC4; d, HM2.2S/pPKC5 (pthN, pthN2); e, HM2.2S/ pPKC9; f, HM2.2S/pPKC12; g, HM2.2S./pPKC15; h, HM2.2S/pPKC16; and i, HM2.2S/pPKC18. Note the water-soaking conferred by pPKC5, pPKC16, and pPKC18. Photo taken 5 days after inoculation.
(Phaseolus vulgaris) cultivar California Light Red Kidney (Sacramento Valley Milling, Inc., Ordbend, CA). Inoculations were as described (10): essentially, bacterial suspensions of Xanthomonas $\left(10^{8} \mathrm{CFU} / \mathrm{ml}\right)$ in sterile tap water were pressure-infiltrated into leaves of 4- to 5-week-old cotton and bean plants. Plants were grown in the greenhouse, transferred to growth chambers before inoculation, and maintained as described (7). Pathogenic symptoms were observed daily and results recorded 2 to 6 days after inoculation.

Construction of subclones and chimeric genes. To isolate and clone $p t h N$, pPKC5.3 was first digested with PvuII, and the $3.5-\mathrm{kb}$ $P v u I I$ fragment carrying most of $p t h N$ was cloned into the SmaI site of pBluescript, forming $\mathrm{pPKC} 13.12$. A 3.0-kb SstII/EcoRI fragment from $\mathrm{pPKC} 8.37$, containing the remainder of $p t h N$, was direc-

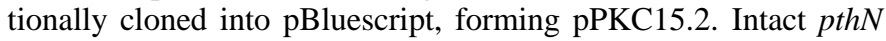
was then restored by replacing the $0.5-\mathrm{kb}$ AatII/HindIII fragment in $\mathrm{pPKC} 13.12$ with the $1.2-\mathrm{kb}$ AatII/HindIII fragment from pPKC15.2, forming pPKC18.5. The 4.0-kb fragment containing reconstituted $p t h N$ in pPKC18.5 was digested with SstI and HindIII and recloned into pUFR047, forming pPKC19.4.

To isolate and clone $p t h N 2$, subclone pPKC5.5 was digested with SstII and HindIII, generating a 5.7-kb fragment. The fragment was recloned directionally into pBluescript KS to generate pPKC9.1. Activity of pthN2 was assayed by recloning it into pUFR053, forming $\mathrm{pPKC} 10.1$.

To test the influence, if any, of the regions of $p t h N$ flanking the $102-b p$ repeats on the specific phenotype conferred by the gene, the tandemly arranged repeats of $p t h N$ were replaced as a unit by the repeats from avrb6. pPKC18.5 ( $p t h N)$ and pUFR135 (avrb6) were double-digested with StuI and AatII, and the 1.6-kb StuI/ AatII fragment containing the 102-bp repeats of avrb6 and the 5.4$\mathrm{kb}$ StuI/Aat II fragment containing the $5^{\prime}$ and $3^{\prime}$ ends of $p t h N$ were recovered from an agarose gel and purified by the phenol-freezefracture method (1). The repeat region of $a v r b 6$ was used to replace the repeat region of $p t h N$, resulting in the chimeric avr/pth gene on pPKC22.6. pPKC22.6 was digested with SstI and HindIII, and the $4.0-\mathrm{kb}$ fragment containing the chimeric gene was recloned into pUFR047, forming pPKC24.1. The activity of the chimeric gene was tested by conjugating into strains HM2.2S and $\mathrm{Xcm} 1003$ of $X$. campestris pv. malvacearum and inoculating on cotton.

DNA sequencing and analyses. For sequencing the regions of $p t h N$ outside of the repeats, $p t h N$ was directionally cloned into the

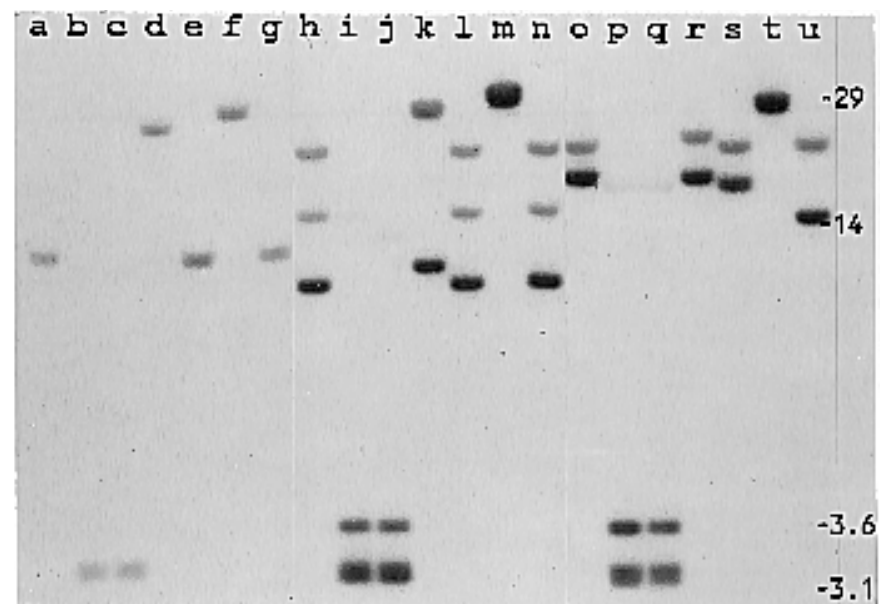

Fig. 2. Southern hybridization of three XcmN clones conferring water-soaking activity to Xanthomonas campestris pv. malvacearum strain HM2.2S. The blot was probed with a ${ }^{32} \mathrm{P}-$ labeled, 3.4-kb internal Bam HI fragment of pthA. Each plasmid was digested with the following enzymes and loaded in order: EcoRI, BamHI, EcoRI/BamHI, KpnI, EcoRI/KpnI, SstI, and EcoRI/ SstI: lanes a to g, pPKC4; lanes h to n, pPKC5; and lanes o to u, pPKC16. Intensely hybridizing bands represent doublets. 
SstI/HindIII sites of pBluescript, forming pPKC18.5. DNA was extracted and purified using the Qiagen (Qiagen Inc., Chatsworth, $\mathrm{CA}$ ) protocol for midi-prep preparation. For sequencing the repeat region of $p t h N$, clone pPKC18.5 was digested with SstI and StuI to generate a sticky end with a $3^{\prime}$ overhang (resistant to Exonuclease III [Promega Corp., Madison, WI]) and a blunt end (susceptible to Exonuclease III), respectively. Exonuclease III was then used to generate a series of nested deletions in the resulting linear fragments. Samples were removed at timed intervals to tubes containing $\mathrm{S} 1$ nuclease to remove the single-stranded tails remaining after Exonuclease III digestion. After filling in the overhanging termini using the Klenow fragment (DNA polymerase), these deletion derivatives were diluted and self-ligated to circularize the plasmids. The ligation mixtures for each time interval were used to transform competent cells. A number of subclones from each time point were then screened to select for appropriately sized deletions.

Sequencing was performed by the ICBR DNA Sequencing Core (University of Florida, Gainesville), using vector-based T7 or T3 promoter primers or custom-synthesized (ICBR DNA Synthesis Core) oligonucleotide primers. Overlapping DNA sequences were assembled using GCG version 7 sequence analysis software package by Genetic Computer Group, Inc. (Madison, WI).

\section{RESULTS}

X. campestris pv. malvacearum genomic library, colony hybridization, and identification of cloned pathogenicity genes. A genomic library of strain $\mathrm{XcmN}$ composed of 846 clones was constructed using cosmid vector pUFR043 and maintained in $E$. coli strain DH5 $\alpha$ MCR. Based on DNA restriction profiles of plasmids from 18 arbitrarily chosen clones, the $\mathrm{XcmN}$ genomic library appeared to contain random inserts with an average size of $36.7 \mathrm{~kb}$. Colony hybridization using pQY104.3 as a probe, which carries a 3.4-kb internal fragment from a member of the Xanthomonas avrlpth gene family, detected 18 hybridizing clones in the library. Eight cosmid clones were selected for activity assays after an examination of their restriction digestion patterns indicated that they likely carried full-length members of the gene family. Three of these eight clones (pPKC5, pPKC16, and pPKC18) conferred strong water-soaking activity to strain HM2.2S of $X$. campestris pv. malvacearum on cotton line Ac44 (Fig. 1). Cosmid clone pPKC4 conferred very weak water-soaking activity, and the remaining four clones had no evident phenotypic effect on the pathogenicity of HM2.2S on Ac44.

Observations of the restriction digestion profiles of the clones restoring water-soaking ability showed that they possessed some DNA fragments in common (Fig. 2; some data not shown). South- ern hybridization of restriction digests of clones conferring strong water-soaking revealed the presence of three EcoRI and three Bam HI fragments of $>3.0-\mathrm{kb}$ each that strongly hybridized to pQY104.3, indicating that each of these clones might carry up to three avr/pth genes. In contrast, only one EcoRI and one BamHI fragment from pPKC4 hybridized to pQY104.3 (Fig. 2; some data not shown).

Molecular characterization of pPKC5 and subcloning. The three hybridizing EcoRI fragments from pPKC5 were subcloned into pUFR047. In addition, subclones with more than one of the five total EcoRI fragments were also obtained by partially digesting pPKC5 with EcoRI and religating to recircularize the plasmids. A restriction map of pPKC5 $(36.7 \mathrm{~kb})$, its subclones, and their relative water-soaking activities in HM2.2S on Ac44 cotton is shown in Figure 3. pPKC5 conferred excellent water-soaking ability to $\mathrm{HM} 2.2 \mathrm{~S}$, at levels not distinguished from the wild-type strain $\mathrm{XcmN}$. Most of the activity of pPKC5 was limited to an $8.7-\mathrm{kb}$ EcoRI fragment present in pPKC5.3. This fragment alone conferred most, but not all, of the activity of pPKC5. Both the 14.0and 10.7-kb fragments hybridized with pQY104.3; neither fragment alone conferred water-soaking activity to HM2.2S, and these fragments were not investigated further.

Activity assays of $\boldsymbol{p t h} \boldsymbol{N}$ and $\boldsymbol{p t h} \mathbf{N} 2$. More extensive restriction mapping of the 8.7-kb EcoRI fragment in subclone pPKC5.3 suggested the presence of two members of the Xanthomonas avr/pth gene family, based on similarities with other family members. These genes were named $p t h N$ and $p t h N 2$. Gene $p t h N 2$, when mobilized into HM2.2S on pPKC10.1 and inoculated on Ac44 cotton, caused weak water-soaking symptoms (Fig. 4). Gene $p t h N$, when mobilized into HM2.2S on pPKC19.4, was found to confer a high level of water-soaking activity on Ac44, almost to that of pPKC5.3 (Fig. 4). When either $p t h N$ or $p t h N 2$ was mobilized into $X$. campestris pv. alfalfae strain $\mathrm{KX}-1$, the transconjugants failed to elicit an HR on P. vulgaris (as is typical of other tested members of the Xanthomonas avr/pth gene family [29; D. W. Gabriel, unpublished data]). No phenotypic changes were detected that distinguished the transconjugants from the KX-1 controls (without pthN or $p t h N 2$ ).

Strain $\mathrm{XcmN}$ and its derivative $\mathrm{Xcm} 1003$ were avirulent on cotton cultivar S295. Transconjugants of Xcm1003 carrying pthN on pPKC19.4 (therefore, carrying additional copies of $p t h N$ ) elicited a stronger (more intense and appearing $12 \mathrm{~h}$ earlier) HR on S295 than $\mathrm{Xcm} 1003$ alone, indicating that $p t h N$ was reacting with the resistance gene B12 in S295. Transconjugants of Xcm1003 carrying $p t h N 2$ on pPKC10.1 (therefore, carrying additional copies of pthN2) elicited an HR on S295 that was not distinguished from that of Xcm1003 alone. Transconjugants of Xcm1003 carrying either $p t h N$ or $p t h N 2$ were virulent on AcB1, AcB2, AcB4, Acb6,

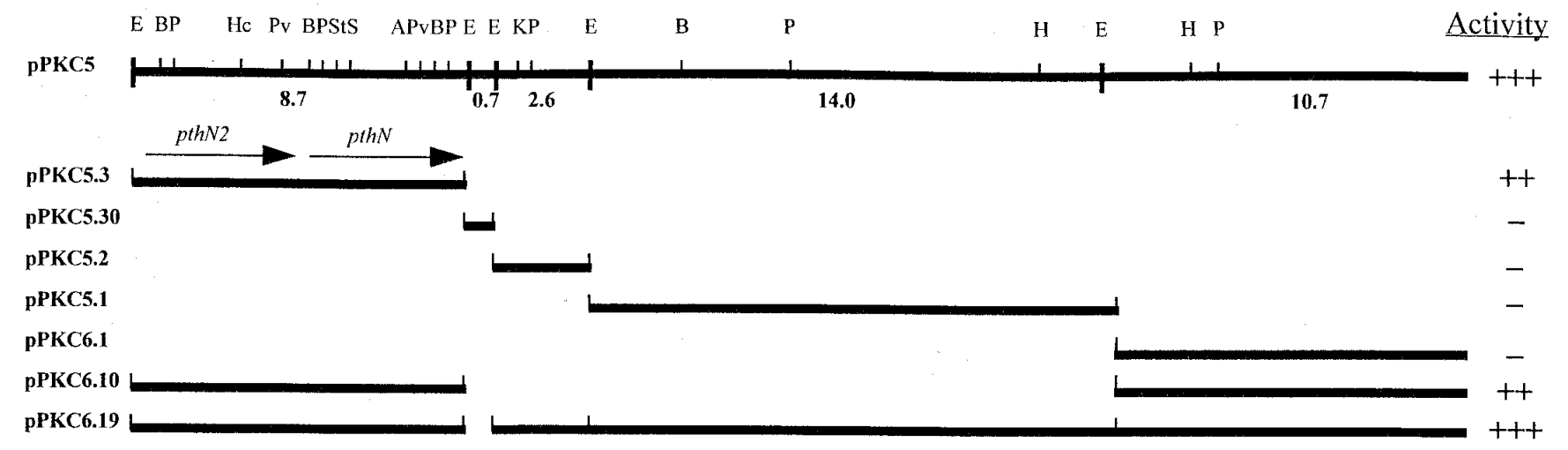

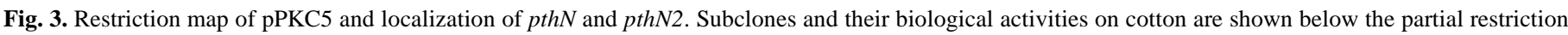

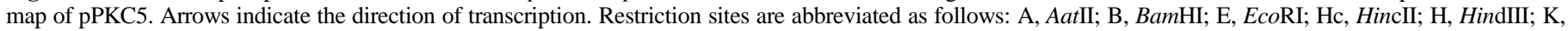
KpnI; P, PstI; Pv, PvuII; S, SstII; and St, StuI. 
Acb7, AcBIn, AcBIn3, Stoneville 2B-S9, Stoneville 20, Mebane B-1, 1-10B, 20-3, 101-102B, Gregg, Empire B4, and DPxP4, reacting similarly to $\mathrm{Xcm} 1003$.

Sequence analysis. Gene $p t h N$ was sequenced completely and is available as GenBank accession number AF016221. The gene was found to be $3.6 \mathrm{~kb}$ in size with a single open reading frame. The central region of this gene was characterized by 13.5 nearly perfect, tandemly arranged, 102-bp direct repeats. As with all other sequenced members of the gene family, the ends of the gene were defined by 62-bp terminal inverted repeats, and the predicted PthN protein carried 13.5 34-amino acid, leucine-rich repeats, a series of leucine zipper-like heptad repeats, and three putative nuclear localization signals (Fig. 5). Little variation was seen in comparisons of the predicted amino acid sequences of different repeats of PthN, except at the twelfth and thirteenth amino acid positions within each repeat (Fig. 5). The amino acid in the twelfth position was always a histidine or asparagine, while that in the thirteenth position was always an isoleucine, aspartate, or glycine.

Activity assays of chimeric pthN with avrb6 repeats in Xcm1003. When the chimeric gene formed by replacing the pthN repeats with those from avrb6 on pPKC24.1 was mobilized into $\mathrm{Xcm} 1003$ and inoculated on cotton line Acb6, a strong HR was observed, similar to that elicited by avrb6 in Xcm1003. When pPKC24.1 was moved into HM2.2S and inoculated on susceptible Ac44 cotton, strong water-soaking, typical of HM2.2S transconjugants carrying avrb6, was observed. The flanking regions of $p t h N$ outside the repeats were, therefore, isofunctional with the equivalent regions of $a v r b 6$, and the repeat regions of $p t h N$ and avrb6 appeared to confer equivalent levels of water soaking to HM2.2S.

\section{DISCUSSION}

We report here the isolation and characterization of two new members of the Xanthomonas avr/pth gene family that function for pathogenicity (water-soaking) in $X$. campestris pv. malvacearum, but that are not recognized as $a v r$ genes by any of the $R$

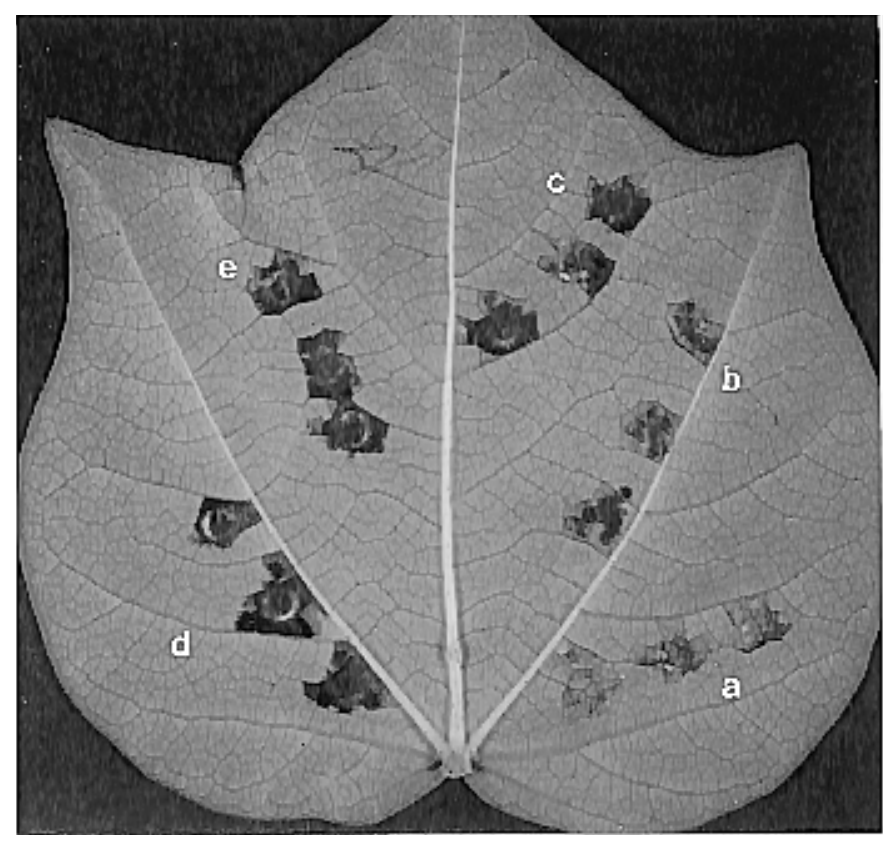

Fig. 4. Water-soaking symptoms caused by $p t h N$ and $p t h N 2$. Subclones were conjugated into Xanthomonas campestris pv. malvacearum strain HM2.2S and inoculated on Acala 44 cotton at high levels $\left(10^{8} \mathrm{CFU} / \mathrm{ml}\right.$; HM2.2S is asymptomatic at $10^{6} \mathrm{CFU} / \mathrm{ml}$ ): a, HM2.2S/pUFR047 (vector); b, HM2.2S/ pPKC10.1 (pthN2); c, pPKC19.4 (pthN); d, pPKC5 (pthN, pthN2); and e, pPKC5.3 (pthN, pthN2). Photo taken 5 days after inoculation. genes currently in commercial use in North America. These genes were cloned from a highly virulent $X$. campestris pv. malvacearum strain, $\mathrm{XcmN}$, that is representative of a group of African strains that evades or defeats all but one gene for resistance against this pathogen in cotton worldwide. This group of strains is even more virulent than the strains belonging to race 18 (previously the most virulent described race) and has been proposed to be categorized as a new race $(2,13)$. Since this strain overcomes the resistance of the previously "immune" line 101$102 \mathrm{~B}$, work is underway to find new sources of resistance to the pathogen (2).

Genes $p t h N$ and $p t h N 2$ belong to a large family of Xanthomonas avr/pth genes that includes pthA of $X$. citri (29); avrb6, avrB4, avrb7, avrBIn, avrB101, avrB102, avrBn, avrB5, avrB103, and avrB104 of $X$. campestris pv. malvacearum $(7,10,33)$; avrBs 3 and avrBs3-2 of $X$. campestris pv. vesicatoria (4,5); and avrXa5, $a v r X a 7$, and $a v r X a 10$ of $X$. oryzae (20). Although most members were originally cloned as avirulence genes, pthA of $X$. citri and $p t h N$ and $p t h N 2$ of $X$. campestris pv. malvacearum were cloned as pathogenicity genes. Many members of the gene family from $X$. campestris pv. malvacearum, originally cloned as $a v r$ genes, have subsequently been found to pleiotropically encode pathogenicity (water-soaking) in compatible interactions on host plants $(31,33)$.

With the exception of $p t h N$ and $p t h N 2$, all previously cloned avr/pth genes from $X$. campestris pv. malvacearum are known to encode multiple avirulence specificities in the source strain on differential host cultivars, and when transferred to other xanthomonads and inoculated on the recipient's differential hosts. Although we have tested $p t h N$ and pthN2 only in X. campestris pv. malvacearum on cotton and in X. campestris pv. alfalfae on bean, the only resistance gene that we have reason to believe "recognizes" pthN as an avr gene is cotton gene B12 in S295. We know of no $X$. campestris pv. malvacearum strains that are virulent on S295 and, therefore, we could not test pthN and pthN2 for avirulence activity on S295 in the usual manner. However, transconjugants of $\mathrm{Xcm} 1003$ carrying additional copies of $p t h N$, but not $p t h N 2$, on a plasmid vector elicited an HR that was more intense and occurred earlier than that elicited by Xcm1003 alone. Both $p t h N$ and $p t h N 2$ confer water-soaking ability to $\mathrm{Xcm} 1003$ and, therefore, both genes are expressed in Xcm1003. This indicates, but does not prove, that the $B 12$ resistance gene in S295 "recognizes" pthN (possibly among other avr genes) as an $a v r$ gene, and provides evidence that there was no suppression of $p t h N$ avirulence activity in Xcm1003 on cotton cultivar S295.

Strain XcmN and its derivative, Xcm1003, are avirulent on S295, but both are virulent on all other cotton lines tested including all standard differentials. Although we knew from using Xcm1003 as a recipient strain in avirulence gene assays on these other cotton lines that it does not suppress the avirulence conferred by genes cloned from other xanthomonads (29,31; D. W. Gabriel, unpublished data), we wanted to test the possibility that some region of $p t h N$ outside of its repeats was able to suppress phenotypic avirulence that would otherwise be conferred by the repeats on other cotton lines. A chimeric construction with the flanking region of pthN and repeats of avrb6, when moved into $\mathrm{Xcm} 1003$ and inoculated on cotton Acb6, conferred the avrb6 HR phenotype. We conclude that the leucine-rich repeats of PthN confer watersoaking without eliciting an HR on all known cotton $R$ genes except $B 12$ in S295 and that the high virulence exhibited by the African strains of $X$. campestris pv. malvacearum is not due to some special property of these strains suppressing avirulence. Rather, the high virulence of the African strains may be achieved because the African strains simply carry fewer avr/pth gene family members than North American strains (about half as many), reducing the chances for $a v r$ gene recognition by $R$ genes, and those avr/pth members that are carried by the African strains 
encode pathogenicity (water-soaking) function(s) without encoding (many) avirulence functions.

Three out of eight cosmid clones from XcmN, identified by hybridization to pQY104.3, conferred strong water-soaking ability to the mutant strain HM2.2S of $X$. campestris pv. malvacearum. Strain HM2.2S was derived from a North American race 4 isolate $(\mathrm{XcmH})$ by repeated marker-eviction (deletion) mutations of members of the Xanthomonas avr/pth gene family in that strain (33). At low levels of inoculum $\left(<10^{6} \mathrm{CFU} / \mathrm{ml}\right)$, the strain is completely asymptomatic, but HM2.2S grows within susceptible cotton plants at the same rate and to the same levels as the wild type; the water-soaking phenotype allows at least 1,600 times more colony forming units to be released to the leaf surface, where they are available for rain splash (33). Southern hybridization of the BamHI and EcoRI single and double digests showed that the clones restoring full water-soaking contained at least three strongly hybridizing Bam HI fragments, whereas the clone causing partial water-soaking contained a single hybridizing Bam $\mathrm{HI}$ fragment. This is consistent with previous observations that members of the avr/pth gene family in X. campestris pv. malvacearum encode weak, but synergistically additive, water-soaking ability, with some members encoding stronger water-soaking than others (33).

The nucleotide sequence of $p t h N$ showed that it is $>94 \%$ identical to all other sequenced members of the Xanthomonas avr/pth

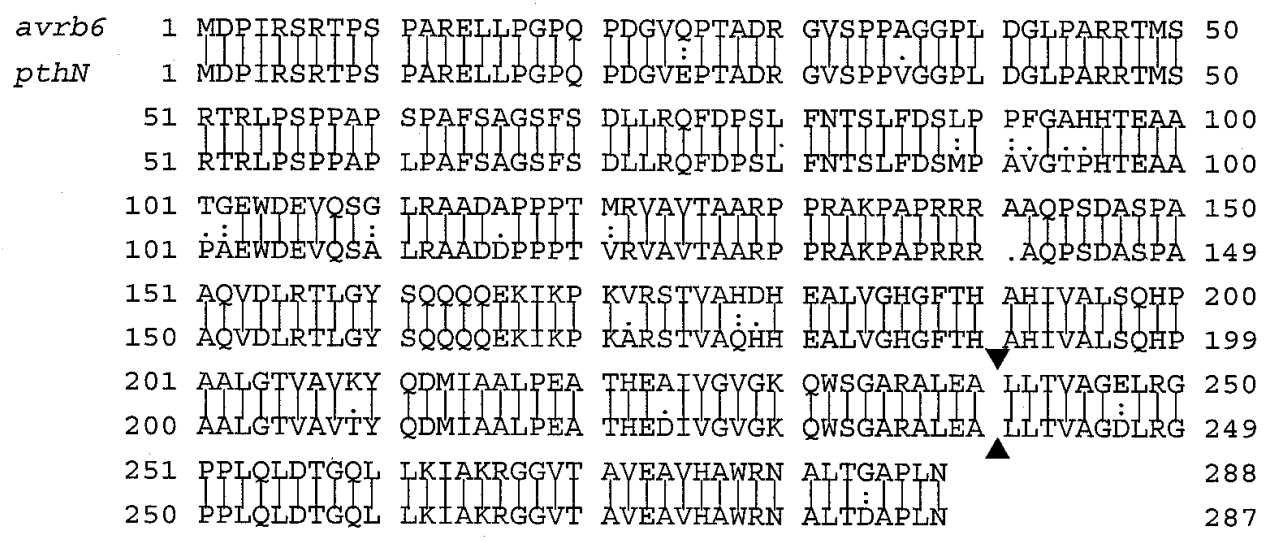

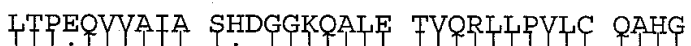
Itithe

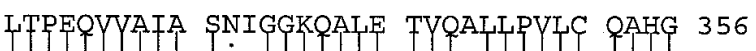

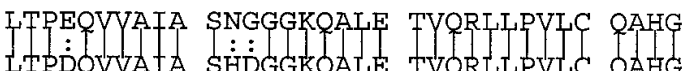

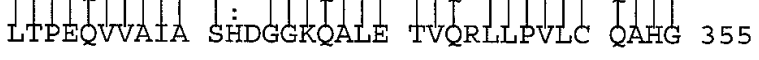

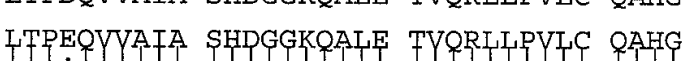

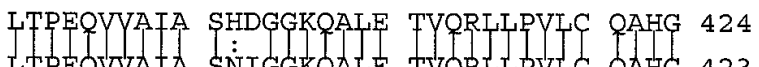

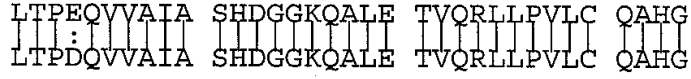

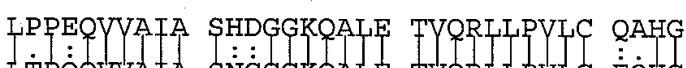

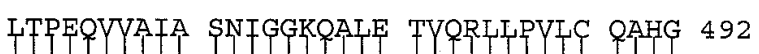

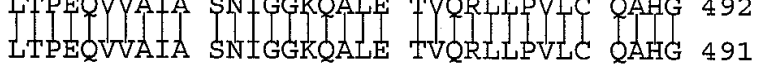

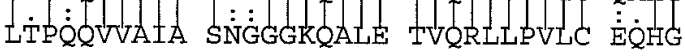
ITLDQYYAIA SNFGGKQAIE TYQRLLPYLC QAHG 560

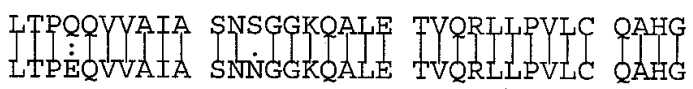

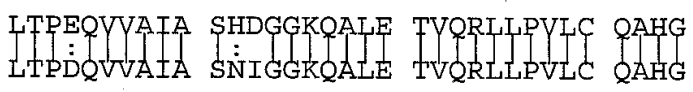

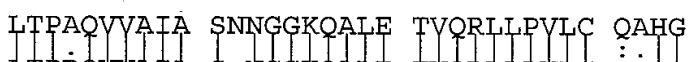

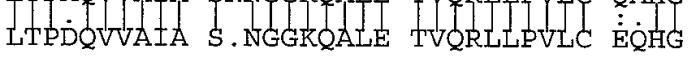

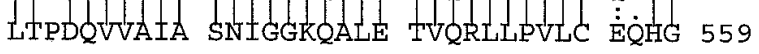
LFPEQYYAIA SHDGGKOAIE TYORLIPYIC OAHG 628 LTPDOVVAIA SHDGGKOALE TVORLLPVLC OAHG 627 LTPEQYYAIA SHDGGKQAIE TYORLLPYLC QAHG 696 LTPDQVVAIA S:ंGGGRQALE TVQRLLPVLC Eं̈G 695 ITPEQYYATA SNGGGRPALE SF 752 LTPAQVVAIA SNIGGKȮALE SI 750

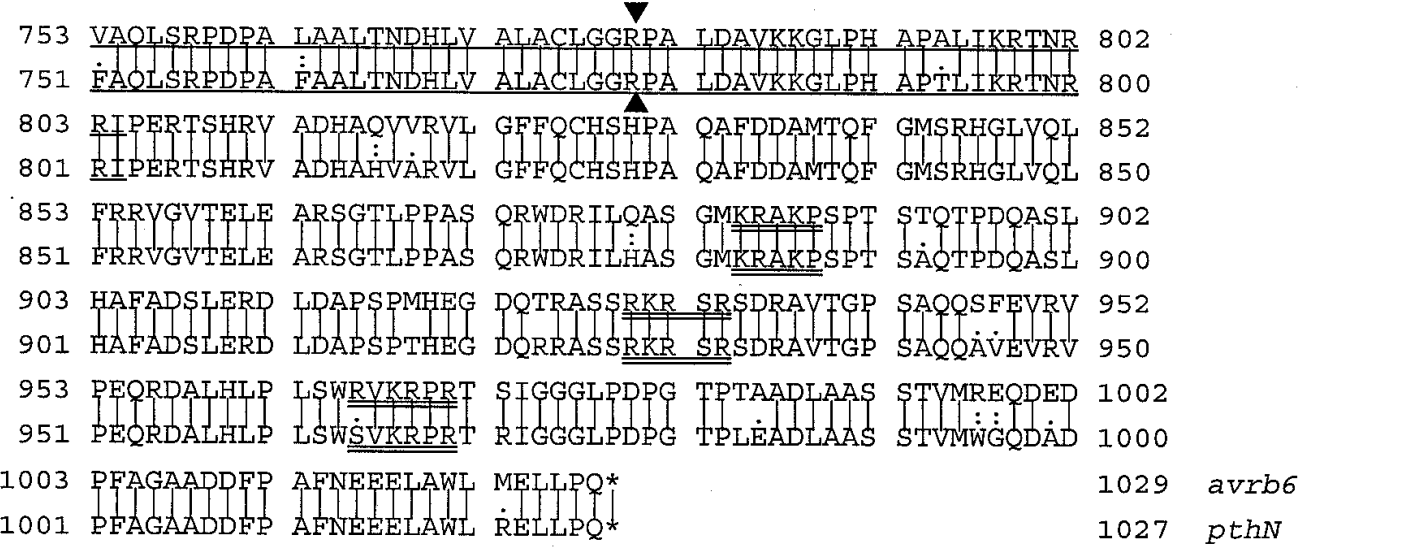

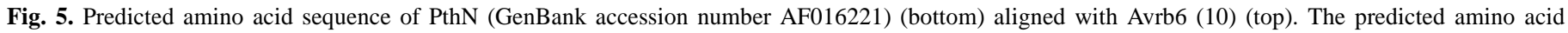

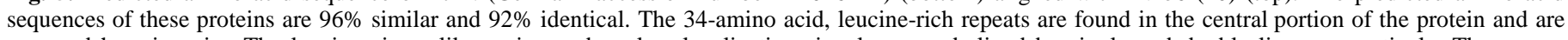

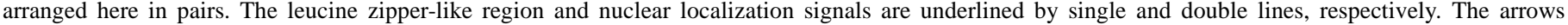

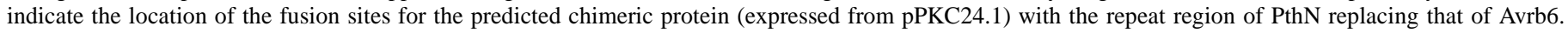

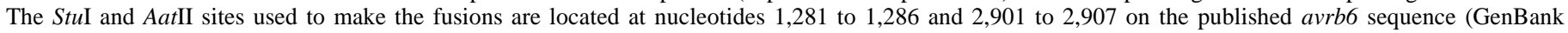
accession number L06634.) 
gene family including $p t h A$ of $X$. citri (29), avrb6 of $X$. campestris pv. malvacearum (31), avrXa10 of X. oryzae (20), and avrBs3 and avrBs3-2 of $X$. campestris pv. vesicatoria $(3,4,5)$. Like all other members of this gene family, pthN had 62-bp terminal inverted repeats similar to those of the $\operatorname{Tn} 3$ family (10) and 102-bp tandem, direct repeats in the central region of the gene. Also, like all other members of the gene family, the 102-bp repeats encoded predicted 34-amino acid, leucine-rich repeats. Although it is known that the 102-bp repeats of members of this gene family determine the host-specific pathogenicity and avirulence functions of members of this gene family $(19,31)$, the mechanism is unknown.

Gene $p t h N$ is functionally similar to avrb6 in terms of the high degree of water-soaking it confers to $X$. campestris pv. malvacearum on cotton. It also carries the same number of repeats (13.5) as avrb6, which is the lowest number of repeats found in any naturally occurring member of the Xanthomonas avr/pth gene family. Perhaps surprisingly, the predicted sequence of PthN was no more related in overall identity to Avrb6 than to most other members (all except AvrXa10 are in the 96.1 to $96.5 \%$ identity range). This was true even when the repeat regions alone were compared. However, in comparisons of the predicted peptide sequences of the repeats of these two water-soaking genes with the predicted peptide sequences of the repeats of all other members sequenced to date, a number of unusual similarities emerged. For example, repeat 6 of PthN is identical to that of Avrb6, and repeats 3, 5, 7, 9, 10, and 12 are nearly identical. In addition, in repeats 5 to 9 of both PthN and Avrb6, but in no other sequenced members, there are alternating polar versus nonpolar amino acids in position 13 of each repeat. Position 13 is the most variable position found in the repeat regions of all members of the gene family sequenced so far. These data are consistent with the findings of Yang and Gabriel (32), who found that deletions in pthA affecting the first eight repeats always affected the ability of $p t h A$ to elicit cankers on citrus, but deletions affecting repeats 9 through 15 sometimes did not. Their data strongly indicate that the location, spacing, and perhaps order of the repeats clustered in positions 1 to 9 may be critical to the phenotype conferred. We are currently constructing chimeric genes containing synthetic repeats to test the hypothesis that repeats 5 to 9 determine the pathogenicity phenotype conferred.

There is no reason to believe that the single $B 12$ gene found in S295 will not be evaded by some recombination event in an African strain, which can occur at high frequency in X. campestris pv. malvacearum (10). Extra copies of pthN2 cloned in Xcm1003 did not confer a stronger HR on S295 than Xcm1003 alone, but extra copies of $p t h N$ did confer a stronger HR. Although this evidence is weak, this may indicate that Xcm1003 is avirulent on S295 because of $p t h N$, but not because of $p t h N 2$ and perhaps the other avr/pth genes found in $\mathrm{Xcm} 1003$. Now that it is known that the protein products of the Xanthomonas avr/pth genes function in the plant cell, the genes can be tested by directly expressing them in the plant cell (14), obviating the need for finding a strain virulent on S295. If even one of the avr/pth genes found in $\mathrm{XcmN}$ can evade recognition by the $B 12$ gene and still confer water-soaking on cotton, it is likely that a new strain will evolve that can also defeat the B12 gene. This possibility is now under investigation.

\section{ACKNOWLEDGMENTS}

This research was supported by the Florida Agricultural Experiment Station and an Overseas Associateship to P. K. Chakrabarty by the Department of Biotechnology, Ministry of Science and Technology, Government of India. University of Florida Agricultural Experiment Station journal series R-05198. We thank G. C. Marlow for technical assistance; M. Essenberg, Oklahoma State University, for seed of the Acala 44-based near-isogenic lines; and K. El-Zik and A. Paterson of Texas A\&M for seed of the standard cotton differential lines.

\section{LITERATURE CITED}

1. Bewsey, K. E., Johnson, M. E., and Huff, J. P. 1991. Rapid isolation and purification of DNA from agarose gels: The phenol-freeze-fracture method. Biotechniques 10:724-725.

2. Bird, L. S. 1986. Half a century of dynamics and control of cotton disease: Bacterial blight. Pages 41-48: Proc. Beltwide Cotton Producers Res. Conf. National Cotton Council of America, Memphis, TN.

3. Bonas, U., Conrads-Strauch, J., and Balbo, I. 1993. Resistance in tomato to Xanthomonas campestris pv. vesicatoria is determined by alleles of the pepper-specific avirulence gene avrBs3. Mol. Gen. Genet. 238:261-269.

4. Bonas, U., Stall, R. E., and Staskawicz, B. 1989. Genetic and structural characterization of the avirulence gene, avrBs3 from Xanthomonas campestris pv. malvacearum. Mol. Gen. Genet. 218:127-136.

5. Canteros, B., Minsavage, G., Bonas, U., Pring, D., and Stall, R. 1991. A gene from Xanthomonas campestris pv. vesicatoria that determines avirulence in tomato is related to avrBs3. Mol. Plant-Microbe Interact. 4: 628-632.

6. Chen, J., Roberts, P. D., and Gabriel, D. W. 1994. Effects of a virulence locus from Xanthomonas campestris $528^{\mathrm{T}}$ on pathovar status and ability to elicit blight symptoms on crucifers. Phytopathology 84:1458-1465.

7. De Feyter, R., and Gabriel, D. W. 1991. At least six avirulence genes are clustered on a 90-kilobase plasmid in Xanthomonas campestris pv. malvacearum. Mol. Plant-Microbe Interact. 4:423-432.

8. De Feyter, R., and Gabriel, D. W. 1991. Use of a cloned DNA methylase genes to increase the transfer frequency of foreign genes into Xanthomonas campestris pv. malvacearum. J. Bacteriol. 173:6421-6427.

9. De Feyter, R., Kado, C. I., and Gabriel, D. W. 1990. Small, stable shuttle vectors for use in Xanthomonas. Gene 88:65-72.

10. De Feyter, R., Yang, Y., and Gabriel, D. W. 1993. Gene-for-genes interactions between cotton $R$ genes and Xanthomonas campestris pv. malvacearum avr genes. Mol. Plant-Microbe Interact. 6:225-237.

11. Endrizzi, J. E., Turcotte, E. L., and Kohel, R. J. 1985. Genetics, cytology, and evolution of Gossypium. Pages 271-375 in: Advances in Genetics. Vol. 23. E. W. Caspari and J. G. Scandalios, eds. Academic Press, Orlando, FL.

12. Figurski, D. H., and Helinski, D. R. 1979. Replication of an origin-containing derivatives of plasmid RK2 dependent on a plasmid function provided in trans. Proc. Natl. Acad. Sci. U.S.A. 76:1648-1652.

13. Follin, J. C., Girardot, B., Mangano, N., and Benitez, R. 1988. New results on inheritance of immunity to bacterial blight, Xanthomonas campestris pv. malvacearum (Smith) Dye race 18 and 20 in cotton plant (Gossypium hirsutum L.). Coton Fibres Trop. 43:167-174.

14. Gabriel, D. W. 1997. Targeting of protein signals from Xanthomonas to the plant nucleus. Trends Plant Sci. 2:204-206.

15. Gabriel, D. W. The Xanthomonas avr/pth gene family. In: Plant-Microbe Interactions. G. Stacey and N. T. Keen, eds. Chapman and Hall, London. In press.

16. Gabriel, D. W., Burges, A., and Lazo, G. R. 1986. Gene-for-gene recognition of five cloned avirulence genes from Xanthomonas campestris pv. malvacearum by specific resistance genes in cotton. Proc. Natl. Acad. Sci. U.S.A. 83:6415-6419.

17. Gabriel, D. W., and De Feyter, R. 1992. RFLP analyses and gene tagging for bacterial identification and taxonomy. Pages 51-66 in: Molecular Plant Pathology. Vol. 1, A Practical Approach. S. J. Gurr, M. J. McPherson, and D. J. Bowles, eds. IRL Press, Oxford.

18. Gabriel, D. W., and Rolfe, B. G. 1990. Working models of specific recognition in plant-microbe interactions. Annu. Rev. Phytopathol. 28:365-391.

19. Herbers, K., Conrads-Strauch, J., and Bonas, U. 1992. Race-specificity of plant resistance to bacterial spot disease determined by repetitive motifs in a bacterial avirulence protein. Nature 356:172-174.

20. Hopkins, C. M., White, F. F., Choi, S.-H., Guo, A., and Leach, J. E. 1992. Identification of a family of avirulence genes from Xanthomonas oryzae pv. oryzae. Mol. Plant-Microbe Interact. 5:451-459.

21. Kolmer, J. A., Dyck, P. L., and Roelfs, A. P. 1991. An appraisal of stem and leaf rust resistance in North American hard red spring wheats and the probability of multiple mutations to virulence in populations of cereal rust fungi. Phytopathology 81:237-239.

22. Lawrence, G. J., Mayo, G. M. E., and Shepherd, K. W. 1981. Interactions between genes controlling pathogenicity in the flax rust fungus. Phytopathology 71:12-19.

23. Lazo, G. R. 1987. Genetic analysis of intraspecific variation in pathovars of Xanthomonas campestris. Ph.D. thesis. University of Florida, Gainesville.

24. Lazo, G. R., Roffey, R., and Gabriel, D. W. 1987. Pathovars of Xanthomonas campestris are distinguishable by restriction fragment length polymorphisms. Int. J. Syst. Bacteriol. 37:214-221.

25. Mundt, C. C. 1991. Probability of mutation to multiple virulence and durability of resistance gene pyramids: Further comments. Phytopathology 81:240-242. 
26. Samborski, D. J., and Dyck, P. L. 1968. Inheritance of virulence in wheat leaf rust on the standard differential wheat varieties. Can. J. Genet. Cytol. 10:24-32.

27. Sambrook, J., Fritsch, E. F., and Maniatis, T. 1989. Molecular Cloning: A Laboratory Manual. 2nd ed. Cold Spring Harbor Laboratory Press, Cold Spring Harbor, NY.

28. Swarup, S., De Feyter, R., Brlansky, R. H., and Gabriel, D. W. 1991. A pathogenicity locus from Xanthomonas citri enables strains from several pathovars of $X$. campestris to elicit cankerlike lesions on citrus. Phytopathology 81:802-809.

29. Swarup, S., Yang, Y., Kingsley, M. T., and Gabriel, D. W. 1992. A Xanthomonas citri pathogenicity gene, pthA, pleiotropically encodes gratuitous avirulence on nonhosts. Mol. Plant-Microbe Interact. 5:204-213.
30. Wallace, T. P., and El-Zik, K. M. 1989. Inheritance of resistance in three cotton cultivars to the HV1 isolate of bacterial blight. Crop Sci. 29:1114-1119.

31. Yang, Y., De Feyter, R., and Gabriel, D. W. 1994. Host-specific symptoms and increased release of Xanthomonas citri and X. campestris pv. malvacearum from leaves are determined by the 102-bp tandem repeats of $p t h A$ and $a v r b 6$, respectively. Mol. Plant-Microbe Interact. 7:345-355.

32. Yang, Y., and Gabriel, D. W. 1995. Intragenic recombination of a single plant pathogen gene provides a mechanism for the evolution of new host specificities. J. Bacteriol. 177:4963-4968.

33. Yang, Y., Yuan, Q., and Gabriel, D. W. 1996. Watersoaking function(s) of XcmH1005 are redundantly encoded by members of the Xanthomonas avr/pth gene family. Mol. Plant Microbe Interact. 9:105-113. 